\title{
Apostle Battery Table Bay Fire Command
}

\author{
Col L.A. Crook, SM, JCD*
}

Although it had been agreed at an Imperial Defence Committee meeting in London in June, 1933, that South African coast defences should be modernised at a cost of $£ 130000$ - which today seems a quite ridiculous amount - none of the recommendations had been completed when World War II broke out more than six years later. $^{1}$

The recommendations included the conversion of two 9.2-inch guns at Simons Town and two at Cape Town on 15-degree mountings to 35-degree mountings, which would greatly increase their range, and the emplacement of two 35-degree 9.2-inch guns to replace the two obsolete 6 -inch quick-firing guns in a so-called state of care and preservation, unmanned and gathering sand, on the Bluff at Durban. ${ }^{2}$

These recommendations had been made as part of a plan to upgrade port defences throughout the British Commonwealth and had come about as the result of Japan's increasingly aggressive stance in the East including her occupation of Manchuria and her withdrawal from the League of Nations in March 1933, and the rise to power of Adolf Hitler in Germany. Germany's subsequent withdrawal from the Disarmament Conference and the League of Nations gave impetus to the modernisation of British naval bases throughout the world. ${ }^{3}$

On 9 December, 1938, the British Admiralty advised the Commander-in-Chief, South Atlantic that it had been agreed to provide the South African Government, on repayment, with two 15inch guns and mountings for Robben Island and two 9.2-inch guns on 35 degree mountings at Duiker Point for the defence of Cape Town. It would not be possible, however, to supply the guns for Robben Island in under four years and the 9.2-inch mountings before 1944. Col. P. de Waal who had been placed in charge of coast defences in September 1938 favoured the 9.2inch gun, arguing that in a given time they could deliver more fire than the larger guns.

His opinion obviously won the day for a month after war was declared the South African Prime Minister replied to a letter from Mr Churchill and said that the 15-inch guns were considered an extravagant over-insurance. He asked instead if Britain could arrange early delivery of a two-gun battery of high-angle 9.2-inch guns for Robben Island and two high-angle mountings for the battery then being built at Llandudno, which would also form part of the Simons Town defences. ${ }^{4}$ Both the Robben Island Battery and Apostle Battery (initially called Duiker Point Battery) were designed by Col. Piet de Waal to fire over the mountains of the Cape Peninsula, to support the Simons Town guns in the event of an attack on the naval installations there.

An enormous programme of necessary defence works was put into operation at the commencement of the war and such was the urgency that red tape was cut to a minimum and often ignored altogether. Situated on the mountainside above the picturesque bay of Llandudno on the road from Cape Town via Camps Bay to Hout Bay, Apostle Battery was built on ground which formed part of the farm "Oude Kraal" of 559 morgen which had been granted as a Quitrent Grant to Michiel van Breda on 18 August 1836. Transferred from his estate to that of his son, Dirk Gysbert van Reenen van Breda in early 1851, the portion on which the Battery now stands was only transferred to the Government of the Union of South Africa from Dirk'van Breda's Estate on 19 September, 1941, a little more than a year after construction commenced. ${ }^{5}$

The initial work consisted of construction of 9.2inch emplacements, Battery Plotting Room, Fortress Plotting Room, Engine Room, Battery Observation Posts, Command Post, living quarters and other buildings.

By October, 1940, the work had long been completed. The bungalows were, however, occupied by Coast Artillery and Anti-Aircraft recruits, the battery being used as a training centre. On 4 December, 1940, all equipment was put on Care and Maintenance and the Artillery staff were transferred to Docks Battery, at the entrance to Table Bay harbour. ${ }^{6}$

One of the war-time stories about Apostle concerns Captain L.H. Jordaan, a young Staff Offi- 
cer Fortifications at Cape Command in early 1940. When the Fortifications Section had completed the battery at the end of March the Coast Artillery Technical Section did not have any guns to mount. Captain Jordaan, not impressed by the slow delivery of the 9.2-inch pieces, secured two bluegum trees from Newlands forest and had them cut down to the same size as the guns. They were painted and mounted in the emplacements to give the appearance that the battery was armed. ${ }^{7}$

In May the following year two 6-inch MK XIX field guns were mounted on the battery and it became a Counter-Bombardment Battery, replacing Lion Battery in this role. By December, 1940, one 9.2-inch MK VII gun had been mounted on Robben Island and another was to follow in July, 1941.

The last parent gun shoot from Lion Battery had in fact taken place in 1935 and since then only sub-calibre guns had been fired. This was the result of protests by Green and Sea Point residents who had complained that the concussion caused by the parent gun shoots resulted in unwarranted damage to property along the slopes of Signal Hill. It was for this reason that Lion Battery had been replaced as a Counter Bombardment Battery. The first 9.2-inch gun, serial F.2, was dismounted on 20 October, $1941 .{ }^{8} \mathrm{~F} .1$ gun which was a 9.2-inch MK X on a MK 5 mounting - Registered No 2508, was removed in late March, 1942, and on 6 April it was transferred to Apostle where it was installed in No 1 Emplacement. With the two 6-inch field guns Apostle was able to function as a three-gun counter-bombardment battery.

With the threat to Egypt paramount in their minds during July, 1942, the United Kingdom authorities felt compelled to divert all available reinforcements to the Middle East, and a steady flow of shipping passed around the Cape. It was thought unlikely that Japanese aircraft carriers would appear off South Africa but the British Ports Defence Committee nevertheless allocated three more high-angle 9.2-inch guns to South Africa to provide a third gun for the batteries on Robben Island, at Scala above Simons Town and at Apostle Battery. It was agreed that they would be sent as soon as possible, but probably not until August, 1943. With the defence of Durban so vitally important the Committee was informed that Da Gama Battery on the Bluff should take preference over Apostle Battery but it was only a matter of time before Aus- tralia's plea for a higher priority for Port Moresby saw the extra guns being reallocated, with South Africa's consent. ${ }^{9}$

WAAS personnel arrived at Apostle in September to take over B.O.P. duties. They were known as "those intrepid girls", and out of about 450 ASWAAS (Artillery Specialists, Women's Auxiliary Army Service) personnel specially required for service in the coastal batteries, 18 became officers, 31 Staff Sergeants and 49 Sergeants. The remainder were Bombardiers and Lance Bombardiers. They trained initially as Rangefinders but were eventually employed on the B.O.P.'s and F.O.P.'s and plotting rooms at all batteries around the coast, except Saldanha. In June, 1941 all ASWAAS had been permitted to wear Artillery badges and buttons, a privilege very highly prized by all as an indication that their acceptance into the Artillery was complete. They were the only women Gunners* in the British Commonwealth. ${ }^{10}$

Most of the 9.2-inch stores previously held at Lion Battery were handed over to Apostle in the latter half of 1942.

The second 9.2-inch gun, a MK X on a MK IX mounting - Registered No. 51, was received from overseas in August, 1943, and mounted the same month. A test of the mounting was effected on 1 September and thereafter the 6-inch field guns were removed. A reduced state of manning had come into operation the previous month and only one gun was manned and the second went to Care and Maintenance. In December the remaining gun went to Care and Maintenance and the Battery ceased to function operationally, being closed down on 17 December. From that date only a maintenance party was on duty.

The Fortress Instruments were installed in January, 1944, but never used.

Ten months later a further MK 9 mounting - No 88 - was received and it was mounted on the Battery almost immediately, the original MK 5 mounting from Lion Battery being removed to make way for the new one. It was tested and taken into service on 21 December 1944.

On 29 March, 1945, Coastal Defence Microwave radar (CA No 1 MK 2X) was installed and

\footnotetext{
* The accent is on "Gunners"
} 
handed over for use. It functioned as gun laying equipment and operated in conjunction with similar equipment installed at Robben Island and Scala Battery at Simons Town. ${ }^{11}$

Finally, the third 9.2-inch gun, a MKX on a MK IX mounting, which had been allocated by the Ports Defence Committee in July 1942 for installation about a year later, arrived and was installed in late October, 1945. The test rounds were fired on 3 January, $1946 .{ }^{12}$ The three 9.2-inch guns of the battery, carrying the section letter indicator ' $\mathrm{H}$ ' ie $\mathrm{H} 1, \mathrm{H} 2$ and $\mathrm{H} 3$ were situated 491, 471 and 572 feet above mean sea level respectively and had a range of 32500 yards at 35 degree elevation, at supercharge. 550 half super charge cartridges per gun were held at the battery with 250 APC shells, fuse 346 and 25 HE fuze 230 or 45 , per gun.

Three 5 hp electric hoists carried the shells and cartridges from the underground magazines and the power to supply the hoists and all other electrical apparatus at Apostle came from two 120 kilowatt 440/220 volt DC generators driven by 6 cylinder Ruston Diesels. The engine room, or Power House as it was also called, also contained a 24 kilowatt 440/220 volt DC generator driven by a Lister diesel and two 3hp compressors with air reservorrs. A Mercury Arc Rectifier and a DC switchboard completed the equipment. The pump chambers contained three 50hp pumps and a further three $15 \mathrm{hp}$ compressors and oil separators.

Despite all this equipment, an auxiliary Engine Room contained a 5 kilowatt 220 volt DC Fowler generating set with switchboard.

No searchlights were installed at Apostle, night fighting lights being supplied from the CASL's at Mouille Point and Cornelia. Fortress observation posts for Table Bay Fire Command were situated at Blaauwberg, Robben Island, Ridge, Oudekraal, Hout Bay and Slangkop, whilst the Fire Control Post was on Signal Hill.

The Coast Artillery Brigade consisting of eight heavy batteries of which Numbers 1,2 and 5 were located at Table Bay, Simons Town and Robben Island respectively, was revived as a Permanent Force unit at this time, under command of Col. Maurice de Villiers.

The Heavy Batteries were accorded regimental status on 1 September, 1949, becoming 1/5, 2 , $3 / 6$ and 4 Coast Regiments SAA. Because of personnel shortages 1 and 5 and 3 and 6 Batteries had been amalgamated on 15 February 1946. 7 and 8 Batteries had been disbanded as Permanent Force Units but Coast Garrison Force (later Active Citizen Force) batteries numbered from 1 to 8 existed at all the ports.

Coast Artillery was placed under direct control of Director General Land Forces in November 1949 and it became part of the SA Corps of Marines from 1951 to 1955 . The appearance of guided missiles rendered coastal counter-bombardment forces out of date and on advice from abroad it was decided to close down the coastal batteries and to disband the Marines. The batteries and associated radar units were transferred to the SA Navy and almost immediately placed on Care and Maintenance. On 1 January, 1958, the Navy's coast artillery units were disbanded. Many have been stripped of their equipment but Apostle is one that remains essentially the same as it was in its hey-day, ${ }^{13}$ although no longer operational.

Apostle Battery served for many years after the war as holiday accommodation for Permanent Force personnel and from about 1975 until 1983 it was used by the SA Navy Chaplain's Branch for instructional camps. Western Province Command Underwater Club have since used the facilities of the Battery and in early 1989 it was handed to 71 Motorised Brigade as a training camp.

\section{Footnote}

Coast Artillery nomenclature is deceptive as the term "battery" applied both to the individual tactical units of two or more guns but also to the whole administrative unit, which might include four different "batteries" as at Simons Town, where there were Noah's Ark, Queen's, Middle North and Scala batteries before the war. This group of batteries, known as a "Fire Command", was manned by the personnel of the administrative formation known as 2 Heavy Battery (in 1949, 2 Coast Regiment).

While Simons Town had four batteries, Table Bay had only two in 1940, Lion Battery and Wynyard Battery - together known as 1st Heavy Battery.

As can be seen the "Fire Commands' which with Anti-Aircraft and other equipments formed a "Fortress" under a "Fortress Commander", varied in size according to the tactical requirements of the locality and even the individual batteries varied as regards the size and number of their guns. Most 9.2-inch and 6-inch coast batteries in 1940 had two guns (later three), but Queen's Battery had four.

Table Bay Fire Command was increased during the war by the addition of Cornelia Battery on the north of Robben Island (6-inch guns) which guarded the Blaauwberg Channel, and Robben Island Battery (9.2-inch guns), on the southern side of Robben Island, together known as 5th Heavy Battery, and Docks Battery at the entrance to Table Bay Harbour (four naval 12-pdr QF and later a twin 6 pounder of 10cwt (MKII).

A battery built near the Steenbras River Mouth known as Gordon's Bay Battery and armed with 6-inch BL MK XII naval guns was later included in the Simons Town fire command. Also included at a later stage were Docks Battery, Simons Town, and Upper North Battery.

Hout Bay was covered by four 12-pounder QF naval guns at two independent 
batteries known as Fine View and York. These were removed in June, 1944 and stored at Apostle Battery

* Col L.A. Crook SM, JCD, joined the Citizen Force on 1 July, 1949 and commanded Cape Field Artillery from 1973 to 1979. After service as Colonel, artillery 7th Infantry Division he was transferred to the staff of Chief of the Army

\section{References}

1. South Africa at War by H.J. Martin \& N. Orpen (Purnell) Cape Town 1979 p.2.
2. Ibid.
3. Ibid.
4. Ibid p. 27 and Deed Office, Cape Town.

5. Cape Quitrents Vol 8, Folio 35, 18 August 1836 and subsequent Deeds. 6. Apostle Battery Fort Record Book (Army Book 360), Museum of Coast and Anti-Aircraft Artillery, Fort Wynyard.

7. Paratus May 1989 (Short of guns, so he disguised tree-trunks).

8. Lion Battery Fort Record Book history as above.

9. South Africa at War p. 185

10. Look-In After 40 Years - The Story of the Artillery Specialists W.A.A.S. 1941-1946 - by M.H. Hill (Marins Printing) Johannesburg. 1984. Various pages.

11. Militaria 4/2 1974 (The Application of Radar in the UDF During World War II) p. 15

12. Apostle Battery Fort Record Book history.

13. Commando October 1962 (The South African Corps of Marines Captain Deon Fourie) p. 23. 